\title{
Numerical Analysis of Dry Excavation Using a Tie Back Wall Under Static and Dynamic Load
}

\author{
Masih Allahbakhshi, ${ }^{1,}$, Amir Allahbakhshi' \\ ${ }^{1}$ Department of Civil Engineering, Mazandaran University of Technology, Babol, Iran \\ ${ }^{2}$ Department of Mechanical Engineering, Arak University, Arak, Iran
}

Email address:

masih2768@gmail.com (M. Allahbakhshi)

\section{To cite this article:}

Masih Allahbakhshi, Amir Allahbakhshi. Numerical Analysis of Dry Excavation Using a Tie Back Wall Under Static and Dynamic Load. American Journal of Optics and Photonics. Vol. 3, No. 5, 2015, pp. 58-64. doi: 10.11648/j.ajop.20150305.12

\begin{abstract}
Deep excavations are common in urban areas, nearby existing constructions. The support systems have the main function of preserve the stability and control soil displacements close to the excavation. Settlement control of nearby structures is an essential aspect during design and construction. Settlements prediction is usually made by empirical methods and in some cases also by numerical modeling. The paper presents a numerical modeling of a dry excavation by Plaxis program. The program allows the prediction of stress and deformation behavior of different geotechnical constructions using the Finite Element Method. The excavation has been modeled in five stages, in order to reproduce the construction phases. The numerical modeling was capable to reproduce satisfactorily the horizontal profile of the displacements of the diaphragm wall. In relation to settlements, the shape of the settlement profile was quite similar.
\end{abstract}

Keywords: Deep Excavations, Settlements, Stress, Numerical Modeling, Plaxis

\section{Introduction}

Displacements control close to open excavations is an important issue not only at the design phase but also during construction, as long as the damages that eventually may occur can compromise not only the functioning but also the stability of the nearby constructions. The occurrence of high displacements can result in the need of underpinning foundation works of neighboring structures, construction delay and additional costs. Displacements profile close to dry excavations should be estimated during design in order to predict its influence on the nearby constructions and on the urban facilities. The displacements estimations are usually made by empirical methods and also by means of the Finite Element Method. According to Hsieh and Ou (1998), the empirical methods present the advantage of considering all the factors that contribute to displacements occurrence, as long as they are based on observed displacements. On the other hand O'Rourke (1981) emphasizes that although the lateral movements are related to the displacements, forming the conceptual basis for most of the analysis based on the Finite Element Method, deep excavations are commonly executed simultaneously with other construction activities, as relocation of urban facilities, dewatering and pile installation.
The author reports that in some cases soil movements associated to the site preparation are greater than those resulting from the excavation and bracing. Many contributions from different authors in the literature emphasize that although the Finite Element Method is able to predict displacements of the excavation walls, the effective stresses estimations are not so satisfactory.

The present article presents the numerical analysis of a dry excavation. The use of Finite Element Methods in modeling the excavation behavior is discussed, mainly in concern with the distribution of the displacements of the diaphragm wall and the effective stresses.

\section{Prototype Study}

\subsection{Finite Element Analysis}

A series of two-dimensional finite element analyses (FEA) on a prototype dry excavation system was performed in order to understand the deformations trends within the soil mass. The analysis was performed using the finite element program Plaxis software package (professional version 8, Bringkgreve and Vermeer, 1998). Plaxis is capable of handling a wide range of geotechnical problems such as deep excavations, tunnels, and earth structures such as retaining walls and 
slopes. The software allows the automatic generation of six or fifteen node triangle plane strain elements for the soil, and three or five node beam elements for the footing while three or five node elastic elements were used for the geotextile elements. Initial step for analyzing the model is to create the geometry of the model. The geometry characteristics such as width and height of the excavation. The excavation is $25 \mathrm{~m}$ wide and $10 \mathrm{~m}$ deep. $18 \mathrm{~m}$ long diaphragm walls of $0.45 \mathrm{~m}$ thickness are used to retain the surrounding soil. A row of ground anchor is used at each wall to support the walls. The anchor is $10 \mathrm{~m}$ long and is installed at an angle of $45^{\circ}$. On the left side of the excavation a static surface load of $35 \mathrm{kN} / \mathrm{m} 2$ is taken to consider the weight of the building near the excavation and on the right of the excavation a dynamic load of $45 \mathrm{kN} / \mathrm{m} 2$ is consider the weight of the generator foundation near the excavation.Fig.1.



Fig. 1. Schematic view of excavation supported by tie back wall.

The relevant part of the soil consist of three distinct layers. From the ground surface to the depth of $4 \mathrm{~m}$ there is a fill of relatively loose fine sandy soil. Underneath the fill, down to a minimum depth of $18 \mathrm{~m}$, there is a more or less homogeneous layer consisting of dense well-graded sand. This layer is particular suitable for the installation of the ground anchors.

In the initial situation there is a horizontal phreatic level at $4 \mathrm{~m}$ below the ground surface (at the base of the fill layer). Below the sand layer there is a loam layer, which extends to large depth.

\subsection{Finite Element Modeling}

The non-linear behavior of sand was modeled using hardening soil model, which is an elastoplast hyperbolic stress-strain model, formulated in the framework of friction hardening plasticity. The foundation was treated as elastic beam elements based on Mindlin's beam theory with significant flexural rigidity (EI) and normal stiffness (EA). A basic feature of the hyperbolic model is the stress dependency of soil stiffness. The interaction between the Geogrid and soil is modeled at both sides by means of interface elements, which allow for the specification of a reduced wall friction compared to the friction of the soil. The limiting state of stress are described by means of the secant Young's modulus ( $E_{50}^{\text {ref }}$ ), tangent stiffness modulus for primary compression ( $\left.\mathrm{E}_{\text {oed }}^{\text {ref }}\right)$, Poisson's ratio $(v)$, effective cohesion (c), angle of internal friction $(\phi)$, angle of dilatancy $(\psi)$, failure ratio $(\mathrm{Rf})$ and interface reduction factor $\left(\mathrm{R}_{\mathrm{int}}\right)$. The modeled boundary conditions were assumed such that the vertical boundaries are free vertically and constrained horizontally while the bottom horizontal boundary is fully fixed. The software allows the automatic generation of six node triangle plane strain elements for the soil, and three node beam elements for the geogrid. The number of element used in reinforced tests are 250 element while in unreinforced tests the number is 160 . The analyzed model of excavation geometry, generated mesh, and the boundary conditions are shown in Fig. 2. An internal angle of friction and secant Young's modulus ( $E_{50}^{\text {ref }}$ ) representing dense sand conditions derived from a series of drained triaxial compression tests were used for the sand.

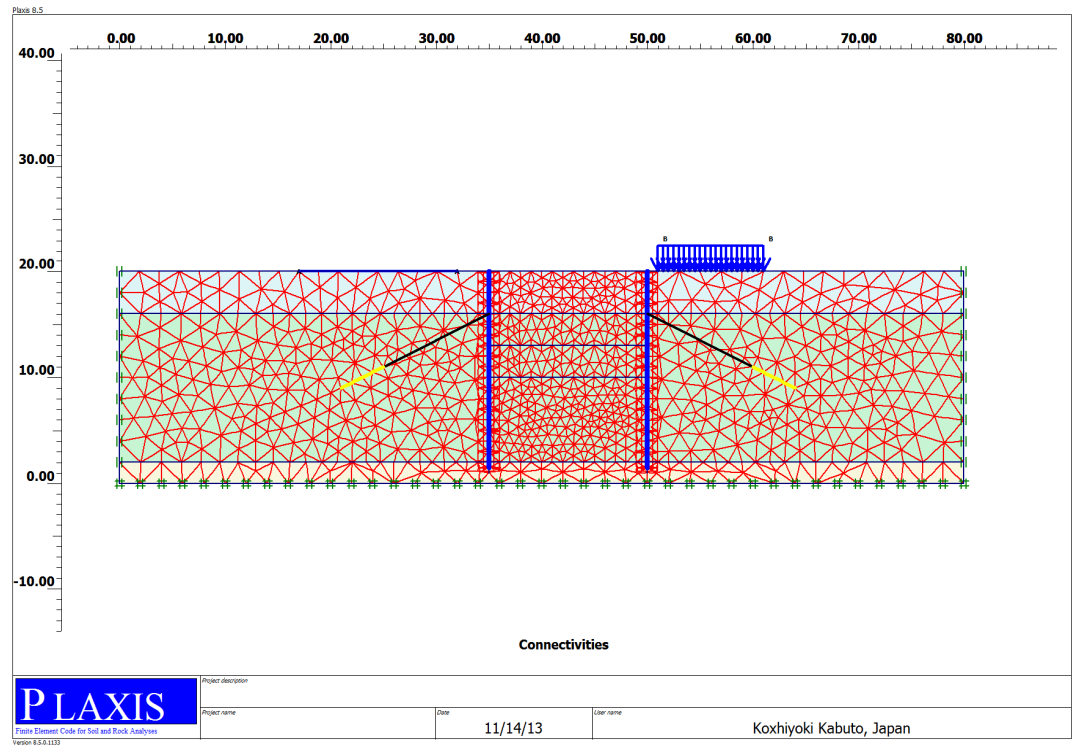

Fig. 2. Model of excavation geometry, generated mesh, and boundary conditions. 
A value of $5 \mathrm{kN} / \mathrm{m}^{2}$ to the undrained cohesion (c) for the fill and $2 \mathrm{kN} / \mathrm{m}^{2}$ for the basement derived from undrained triaxial compression tests was used. Then hyperbolic parameters for the sand, fill and basement were taken from database provided by the software manual as shown in Table.1.

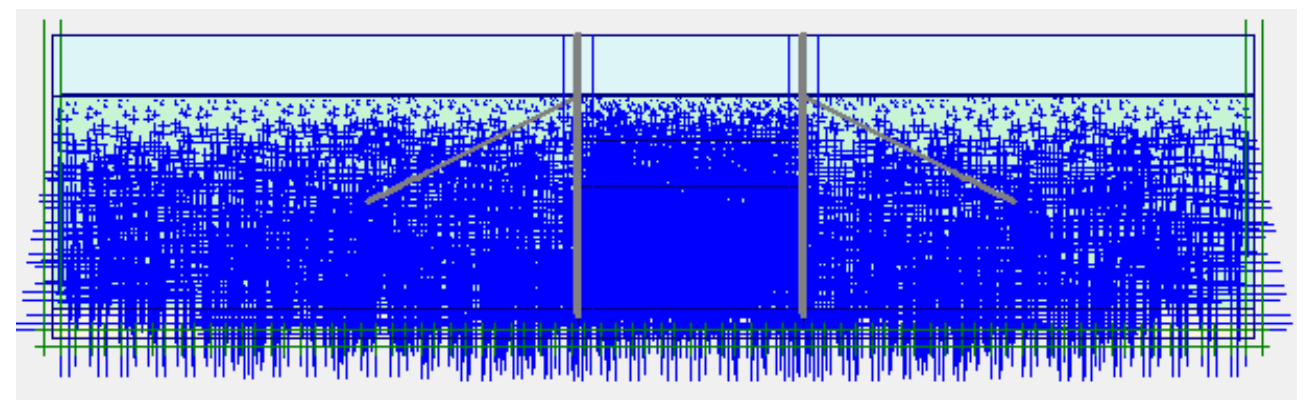

\section{Active pore pressures}

Fig. 3. Active pore water pressure.

Table 1. Mohr-Coulomb model parameters used in the finite element analysis.

\begin{tabular}{|c|c|c|c|c|c|c|}
\hline Parameter & Fill & Sand & Basement & Diaphragm & Geogrid & Anchor \\
\hline Primary loading stiffness $\left(E_{50}^{r e f}\right)\left(\mathrm{kN} / \mathrm{m}^{2}\right)$ & 15000 & 35000 & 20000 & - & - & - \\
\hline Cohesion (c) $\left(\mathrm{kN} / \mathrm{m}^{2}\right)$ & 5 & 0 & 2 & - & - & - \\
\hline Friction angle $(\phi)$ & 35 & 35 & 35 & - & - & - \\
\hline Dilatancy angle $(\psi)$ & 0 & 0 & 0 & - & - & - \\
\hline Soil unit weight $(\gamma)\left(\mathrm{kN} / \mathrm{m}^{3}\right)$ & 6.28 & 15 & 10 & - & - & - \\
\hline Poisson's ratio $(v)$ & 0.30 & 0.30 & 0.25 & 0.15 & - & - \\
\hline Interface reduction factor $\left(\mathrm{R}_{\mathrm{int}}\right)$ & 0.50 & 0.50 & 1 & - & - & - \\
\hline $\mathrm{EA}(\mathrm{kN} / \mathrm{m})$ & - & - & - & 12000000 & 100000 & 200000 \\
\hline $\mathrm{EI}\left(\mathrm{kNm}^{2} / \mathrm{m}\right)$ & - & - & - & 120000 & - & - \\
\hline $\mathrm{W}(\mathrm{kN} / \mathrm{m} / \mathrm{m})$ & - & - & - & 8.3 & - & - \\
\hline$L_{S}(\mathrm{~m})$ & - & - & - & - & - & 2.5 \\
\hline
\end{tabular}

\section{Excavation Stages}

The excavation modeling was performed in five different stages, in order to accurately reproduce the field procedure. It is illustrated in Fig.4. and includes, briefly:

Stage 1: Walls are constructed and the static and dynamic surface loads are activated.

Stage 2: The first $4 \mathrm{~m}$ of the pit is excavated without connection of anchors to the wall. At this depth the excavation remains dry.

Stage 3: The anchor is installed and pre-stressed.

Stage 4: The fourth stage involves further excavation to a depth of $7 \mathrm{~m}$, including the de-watering of the excavation. This involves a groundwater flow analysis to calculate the new pore water distribution, which is a part of the definition of the third calculation stage.

Stage 5: In this stage it is a further excavation (and dewatering) of to the final depth of $10 \mathrm{~m}$.

Except the first stage then we applied static and dynamic load and we consider this stage as a Dynamic calculation all calculation stage are defined as Plastic calculations using Staged construction as Loading input and standard settings for all other parameters. Fig.4.

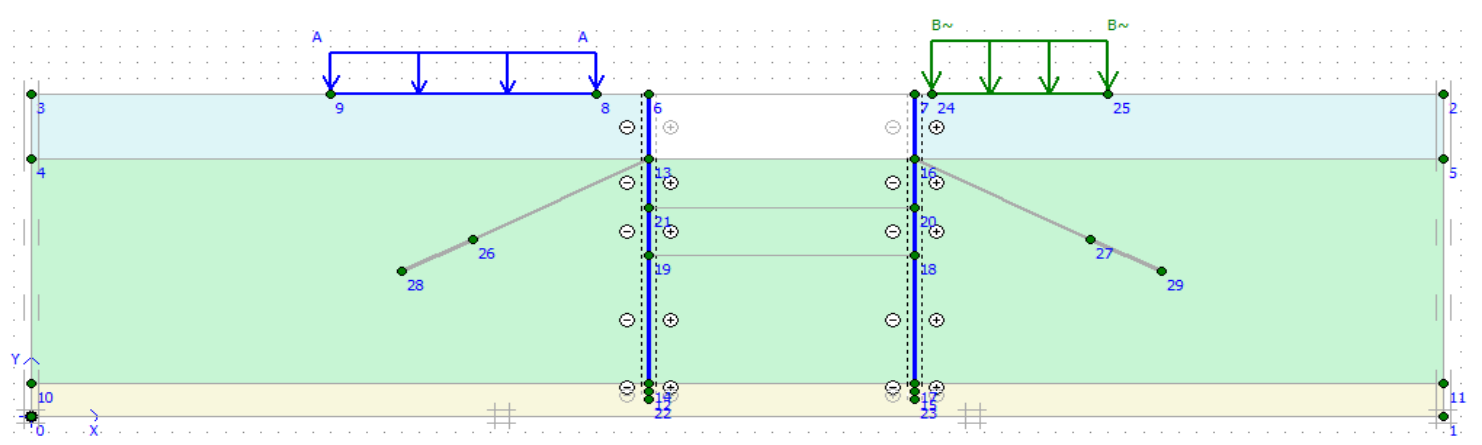

(a) Stage 1 and Stage 2 


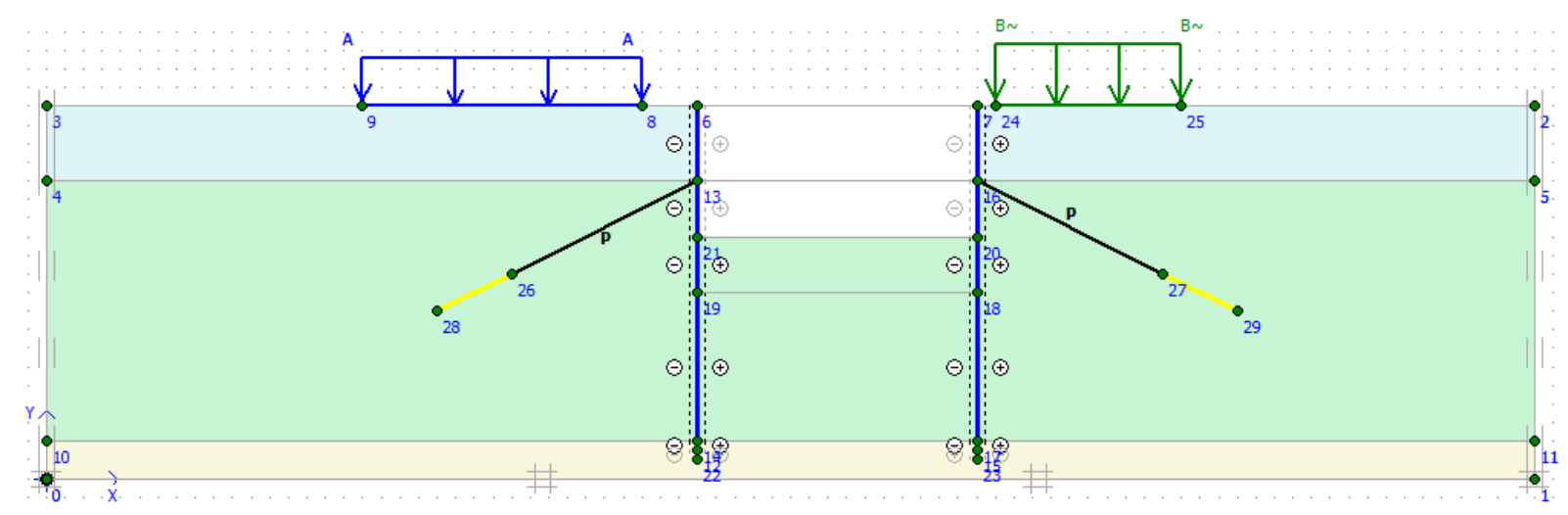

(b) Stage 3 and Stage 4

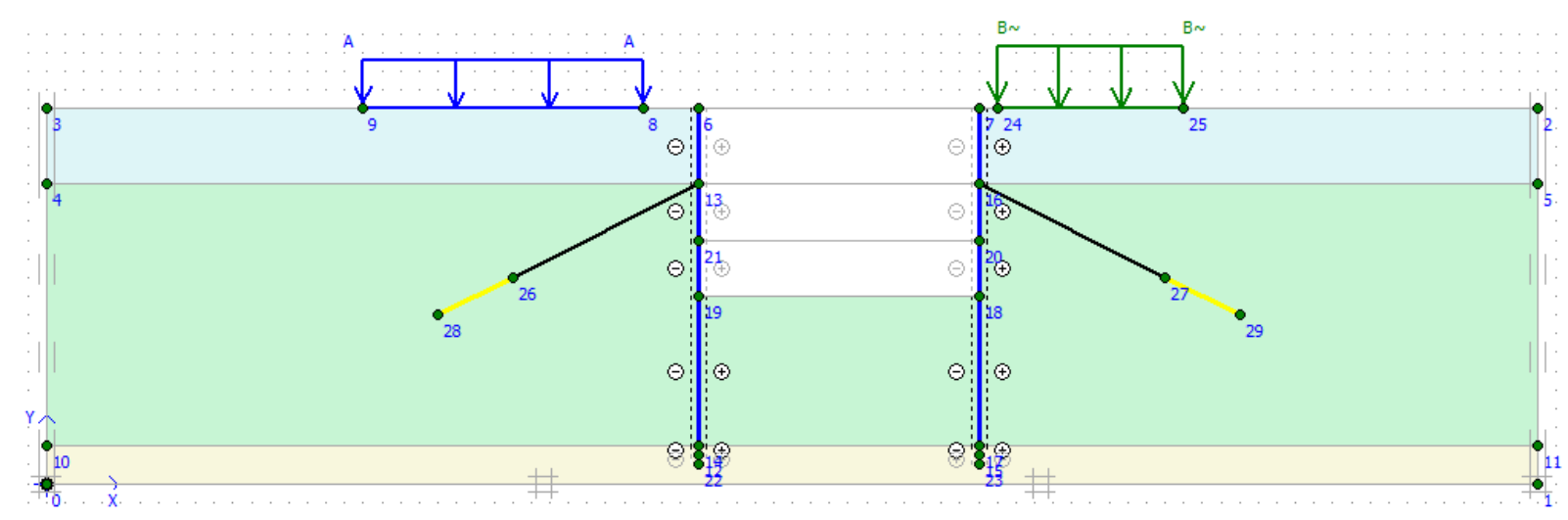

(c) Stage 5

Fig. 4. Excavation stages.

\section{Analyses of the Results}

The numerical analysis admitted the hardening soil model for the representation of the soil behavior. In this item the results obtained in the numerical simulation of the excavation with one tie back are presented for the five excavation stages. They are then compared to the excavation without tie back including the measurements of total, horizontal and vertical displacements and effective stresses.

\subsection{Total Displacements and Deformed Mesh}

The total displacements and deformed mesh estimated numerically are shown in Fig.5. For excavation without tie back and with one tie back in the depth of $4 \mathrm{~m}$ underneath the surface. For excavation without tie back (Fig.5a.) the instrumentation revealed a maximum total displacement close to $302.10^{*} 10^{-3} \mathrm{~m}$ and this value is $12.56^{*} 10^{-3} \mathrm{~m}$ for excavation with one tie back(Fig.5b.).

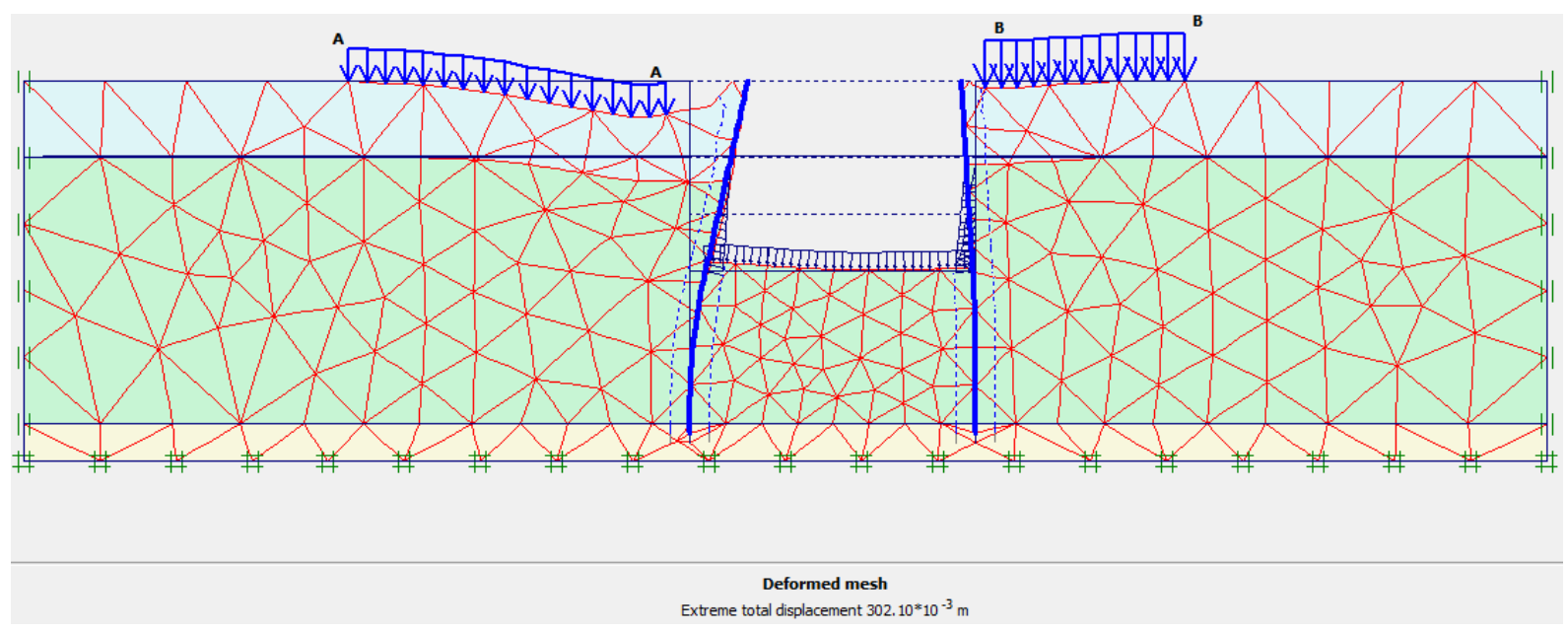

Fig. 5a. Total displacement and deformed mesh for excavation without tie back. 


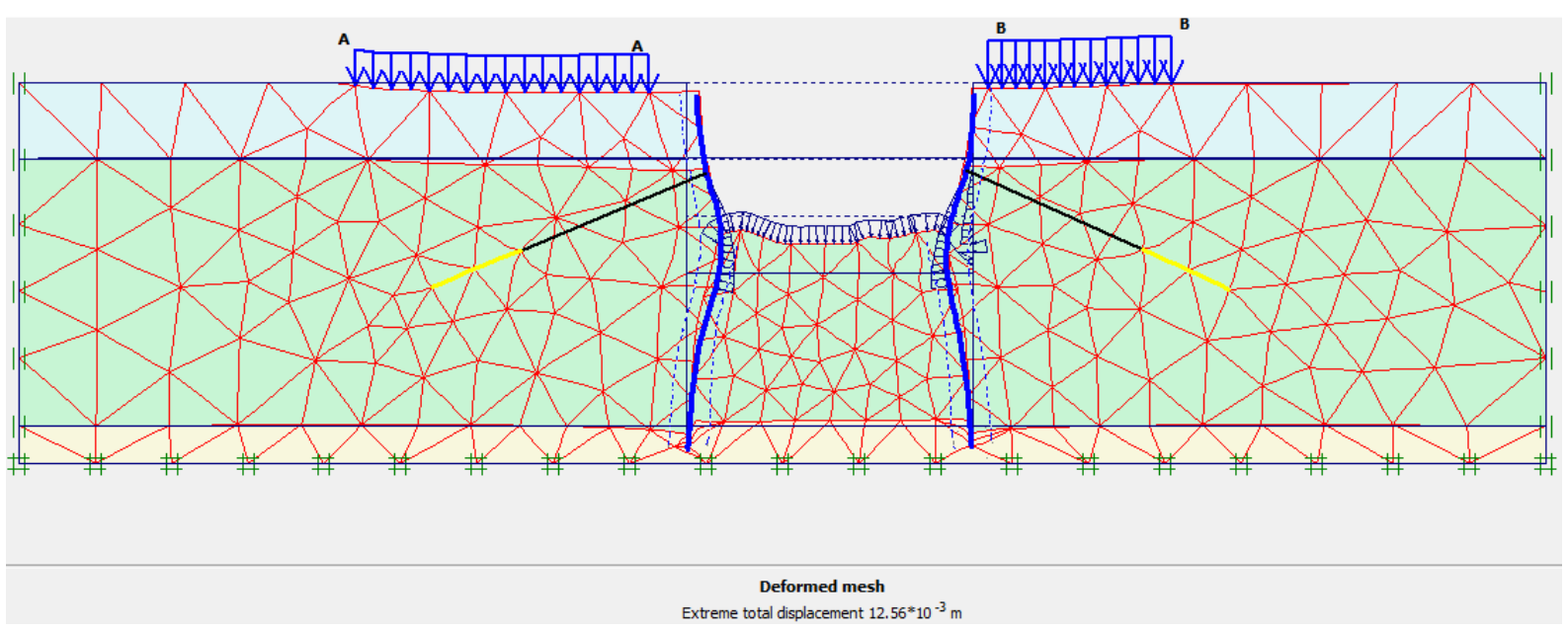

Fig. 5b. Total displacement and deformed mesh for excavation with one tie back.

Fig. 5. Total displacement and deformed mesh.

\subsection{Horizontal Displacements}

As you can see in Fig.6 the horizontal displacement for excavation without tie back is $302.09 * 10^{-3} \mathrm{~m}$ and versus this value is about $10.63 * 10^{-3} \mathrm{~m}$ for excavation with one tie back behind the wall. In fact, the maximum horizontal displacements were located approximately at $4 \mathrm{~m}$ depth from the ground level (especially underneath the static load).

It should be emphasized that the numerical analysis presented attempted to reproduce the different elements involved, like the different soil layers of the soil mass, the various structural elements (the Geogrid, the anchor and the wall), the water flow influence and the interface boundary condition, for instance. The jointed analysis of the different influence of each one of this aspects direct to a complex modelling.

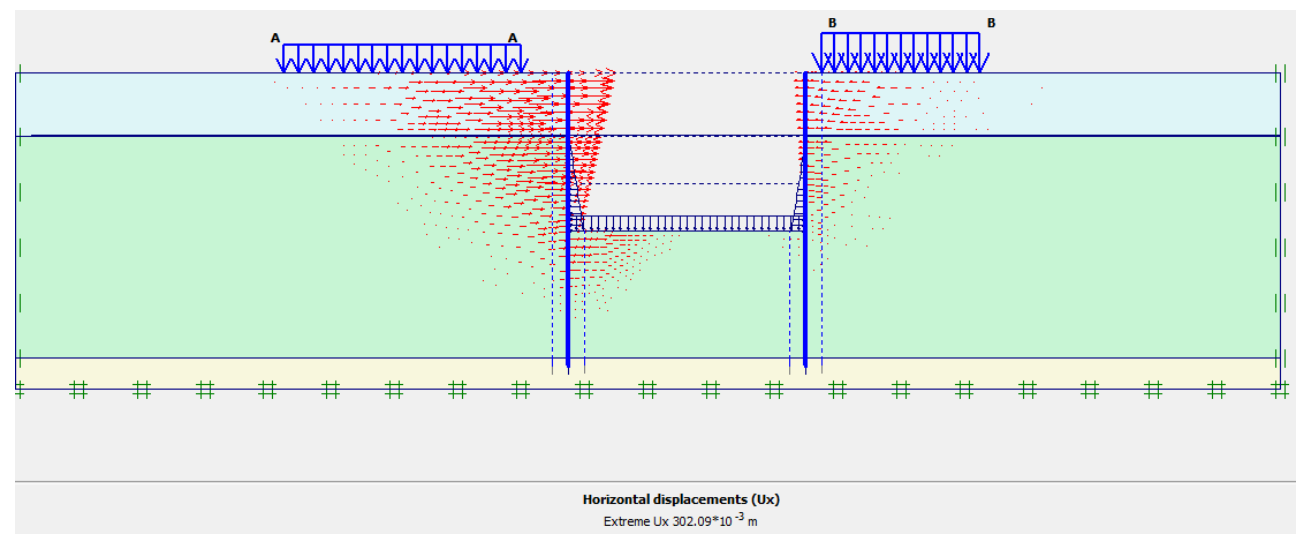

Fig. 6a. Horizontal displacement for excavation without tie back.

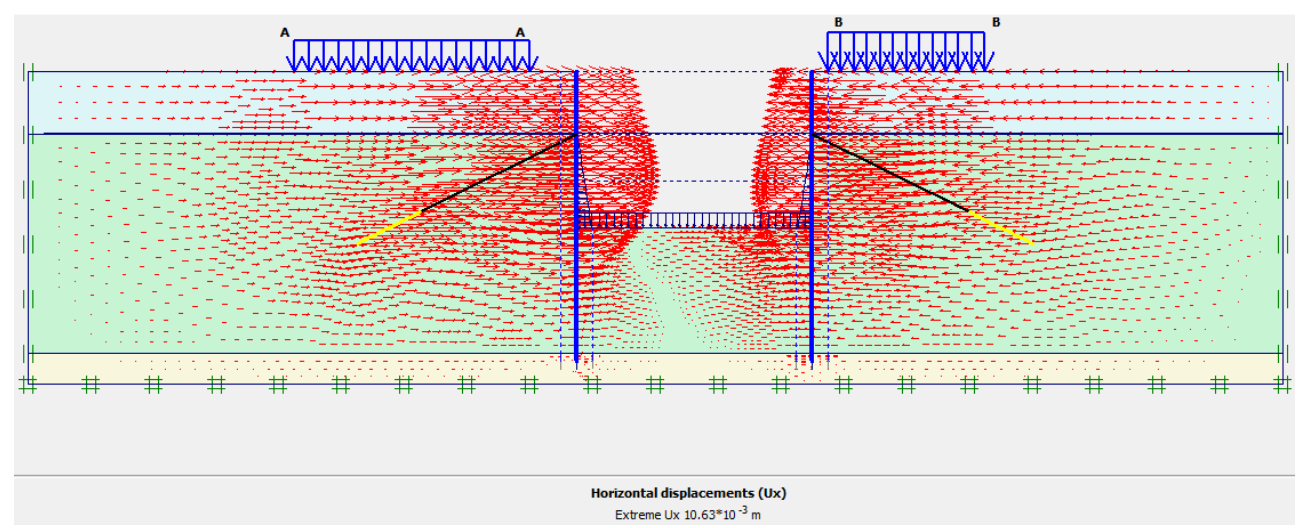

Fig. 6b. Horizontal displacement for excavation with one tie back.

Fig. 6. Horizontal displacement. 


\subsection{Vertical Displacements}

The vertical displacement for excavation without tie back and with one tie back are $194.92 * 10^{-3} \mathrm{~m}$ and $11.27 * 10^{-3} \mathrm{~m}$ respectively. We can see when we use tie back in this problem displacements are decrease in each side of the wall.

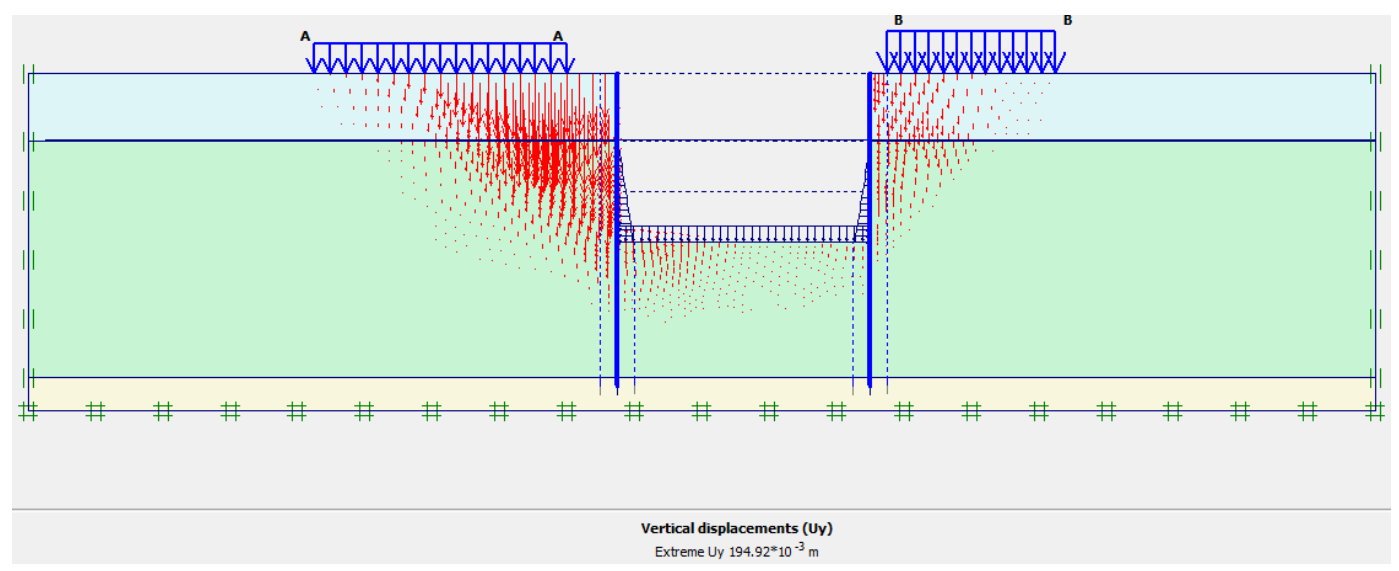

Fig. 7a. Vertical displacement for excavation without tie back.

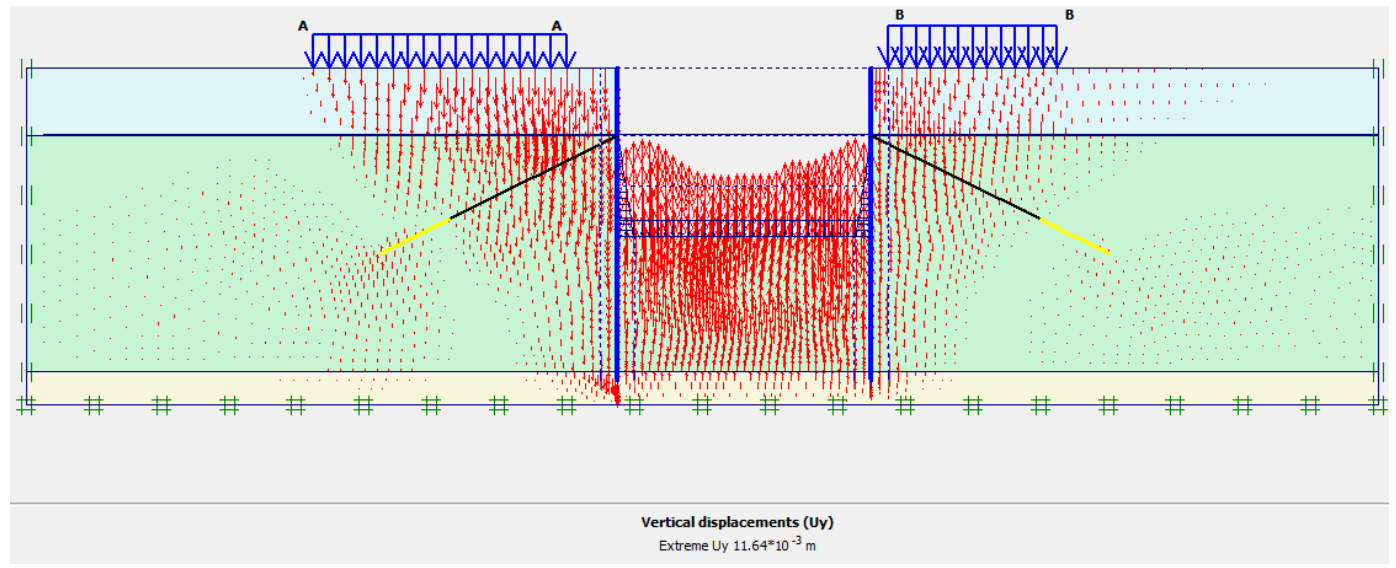

Fig. 7b. Vertical displacement for excavation with one tie back.

Fig. 7. Vertical displacement.

\subsection{Effective Stresses}

The effective stresses estimated numerically by use of Plaxis software are shown in Fig.8. For excavation without tie back and with one tie back. For excavation without tie back (Fig.8a.) the instrumentation revealed effective stresses close to $359.51 \mathrm{kN} / \mathrm{m}^{2}$ and this value is $319.16^{*} 10^{-3} \mathrm{kN} / \mathrm{m}^{2}$ for excavation with one tie back(Fig.8b.).

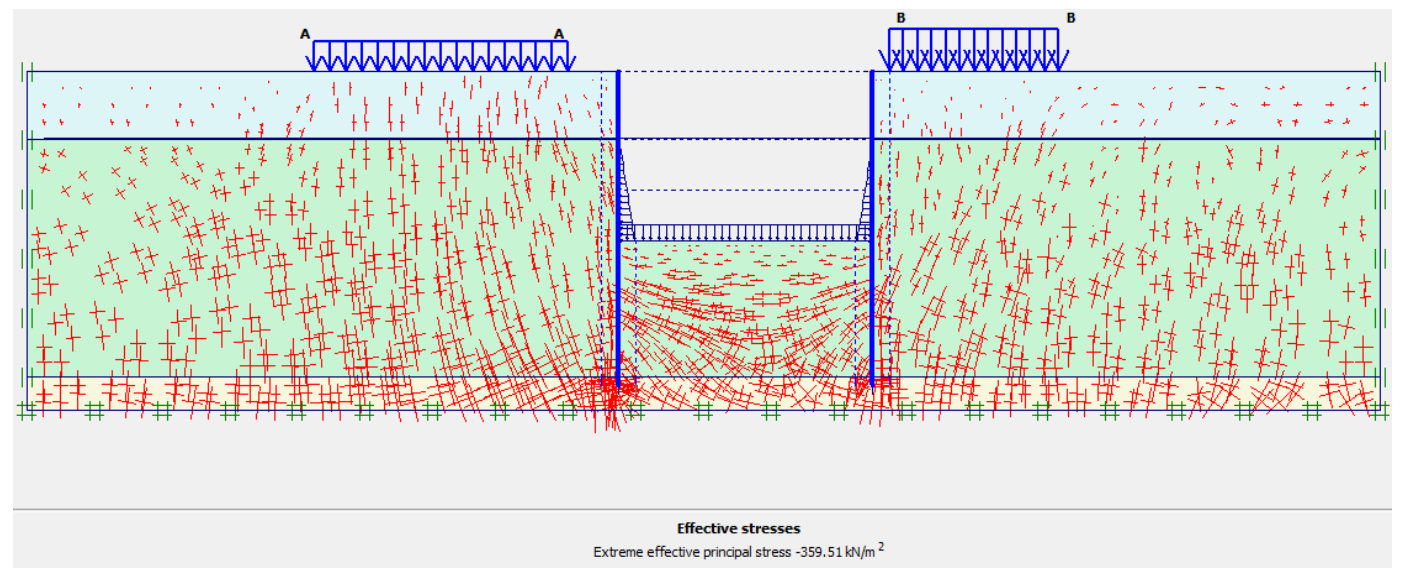

Fig. 8a. Effective stresses for excavation without tie back. 


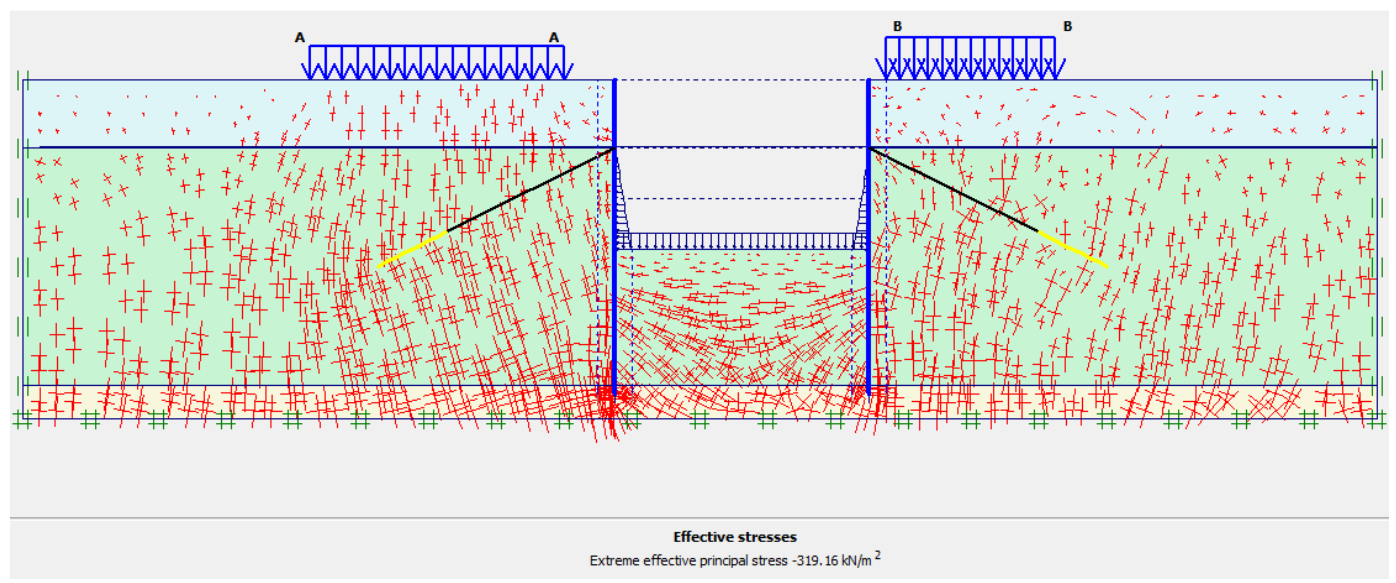

Fig. 8b. Effective stresses for excavation with one tie back

Fig. 8. Effective stresses

\section{Conclusions}

This paper presented a comparison between dry excavation without tie back wall and with one tie back in the depth of $4 \mathrm{~m}$ and behavior of a strutted excavation by the Finite Element Method with Plaxis software under static and dynamic load was considered. The comparisons were established in relation to the displacements and to the effective stresses. The main conclusions concerning each of these aspects are:

(1) The inclusion of tie back wall not only improves the dry excavation behavior but also leads to significant reduction of displacement and effective stresses. With use of one tie back behind the wall total displacements and effective stresses was decreased about $95 \%$ and $11 \%$ respectively. This value was $96 \%$ and $94 \%$ decrease for horizontal and vertical displacements respectively.

(2) For a tie back behind the wall of excavation, an adequate anchorage length for both of nod-nod anchor and Geogrid layer should be provided and an optimum number of tie back should be used.

(3) Using pre stressed nod-nod anchor behind the wall of excavation under laying sand layer decrease displacements and effective stresses and the beneficial effects of the pre stressed nod-nod anchor configuration were evident, in comparison without tie back and with one tie back without pre stress counterparts.

\section{References}

[1] Alves, M. C. M. 1982. Estudo da Estabilidade de Valas Escoradas por Equilíbrio -Limite e Pelo Método dos Elementos Finitos.
[2] Brinkgreve, R. B. J. 2002. Finite Element code for Soil an Rock Analyses - PLAXIS - 2D user's manual. Rotterdam,

[3] EAB (1994). Empfehlungen des Arbeitskreises „Baugruben“. 3. Auflage, Verlag Ernst \& Sohn, Berlin.

[4] Hsieh, P. G., Ou, C. Y. 1998. Shape of Ground Surface Settlement Profiles Caused by Excavation, Canadian Geotechnical Journal, vol.35, p.1004-1017.

[5] Jucá, J. F. T. 1981. Influência de Escavações nos Recalques em Edificações Vizinhas, Tese de Mestrado, COPPE-UFRJ, Rio de Janeiro, Brasil.

[6] Nendza, H., Klein, K. (1974). "Bodenverformung beim Aushub tiefer Baugruben“. Straße Brücke Tunnel 9; pp. 231.

[7] O'Rourke, T. D. 1981. Ground Movements Caused by Braced Excavations, Journal of the Geotechnical Engineering Division, ASCE, vol.107, n.GT9, p. 1159-1178.

[8] PLAXIS (1998). "Finite element code for soils and rocks". PLAXIS, A.A. Balkema, Rotterdam

[9] Potts, D. M., Fourie, A. B. 1984. The Behaviour of a Propped Retaining Wall: Results of a Numerical Experiment, Géotechnique, vol.34, nº.3, p. 383-404.

[10] Stroh, D. (1974). "Berechnung verankerter Baugruben nach der Finite Elemente Methode". Mitteilungen der Versuchsanstalt für Bodenmechanik und Grundbau, TH Darmstadt, Heft 13.

[11] Ulrichs, K.R. (1981). "Untersuchungen über das Trag- und Verformungsverhalten verankerter Schlitzwände in rolligen Böden“. Die Bautechnik, pp. 142. Tese de Mestrado, COPPEUFRJ, Rio de Janeiro, Brasil. Netherlands, Balkema. 